\title{
THE FOREST-HYDROLOGY-POVERTY NEXUS IN CENTRAL AMERICA: AN HEURISTIC ANALYSIS
}

\author{
Andrew Nelson and Kenneth M. Chomitz
}

\begin{abstract}
A 'forest-hydrology-poverty nexus' hypothesis asserts that deforestation in poor upland areas simultaneously threatens biodiversity and increases the incidence of flooding, sedimentation and other damaging hydrological processes. This paper uses rough heuristics to assess the applicability of this hypothesis to Central America. We do so by using a simple rule of thumb to identify watersheds at greater risk of hydrologically significant land use change: these are watersheds where there is a relatively large interface between agriculture and forest, and where this interface is on a steep slope. The location of these watersheds is compared with spatial maps of poverty and forests (for Guatemala and Honduras) and with maps of population and forests (for Central America at large). The analysis is performed for watersheds defined at different scales. We find plausible evidence for a forest-biodiversitypoverty connection in Guatemala, and to a lesser extent in Honduras. In the rest of Central America, there are relatively few areas where forest meets agriculture on steep slopes_either the forest or the slopes are lacking. And the ratio of these forest/agriculture/hillside interfaces to watershed area declines markedly as larger-scale watersheds are considered. This directs attention to relatively small watersheds for further investigation of the 'nexus'.
\end{abstract}

World Bank Policy Research Working Paper 3430, October 2004

The Policy Research Working Paper Series disseminates the findings of work in progress to encourage the exchange of ideas about development issues. An objective of the series is to get the findings out quickly, even if the presentations are less than fully polished. The papers carry the names of the authors and should be cited accordingly. The findings, interpretations, and conclusions expressed in this paper are entirely those of the authors. They do not necessarily represent the view of the World Bank, its Executive Directors, or the countries they represent. Policy Research Working Papers are available online at http://econ.worldbank.org.

\section{Acknowledgements}

This work was supported in part by the Bank-Netherlands Partnership Program, Functional Value of Biodiversity Project. We are grateful to the many agencies that kindly provided data for this study, and to our colleagues on the FVB project for helpful discussions. The boundaries, colors, denominations, and any other information shown on maps herein do not imply, on the part of the World Bank Group, any judgment on the legal status of any territory, or any endorsement or acceptance of such boundaries. 


\section{Motivation and context}

Can forest conservation yield 'bankable' benefits for the developing world? Can it help alleviate poverty? Much attention has been devoted to exploring the potential for using ancillary benefits of conservation to finance or help to justify forest protection (Chomitz and Kumari 1998). Particular attention has focused on hypothesized forest-hydrology-poverty connections.

Some upland deforestation is thought to be undertaken by poor people who clear land for marginal subsistence crops. Such deforestation may directly threaten habitats of high biodiversity value. Deforestation may also result in altered hydrological regimes, contributing to flooding, sedimentation, and landslides. These could in theory damage downstream infrastructure or threaten downstream populations. The threatened populations might be willing to pay upland people to maintain upstream vegetation. Examples of such environmental services compensation schemes exist in Colombia, Costa Rica, Ecuador, India, and New York. (See Pagiola, Bishop, and Landell-Mills 2002; Johnson, White, and Perrot-Maitre 2001; Echavarría 2001.) Deforestation might also have harmful hydrological impacts on local poor people, those immediately downslope from disturbed areas. Hence local watershed management may reduce the environmental vulnerability of poor people.

These hypothesized forest-hydrology-poverty linkages foster hopes that a single policy intervention might simultaneously help to mitigate vulnerability of the poor, biodiversity loss, and economic damages. These hopes apply particularly to Central America, home to many upland poor people and to diverse but threatened biodiversity, and a site of severe flooding and landslides.

Yet the deforestation-hydrology linkage is imperfectly understood by scientists, and even less well understood by the public and policymakers (Calder 2000, Chomitz and Kumari 1998). Contrary to popular belief, for instance, deforestation usually increases, rather than decreases, total water yield. And it is still quite controversial whether upland deforestation is related to downstream flooding in large river basins. On the other hand, there is increasing scientific consensus that deforestation could lead to significant increases in flooding, erosion, 
and sedimentation within smaller watersheds (Kiersch and Tognetti 2002; van Noordwijk, Richey, and Thomas 2003).

Our goal is to get a rough empirical fix on the applicability of the deforestation-hydrologypoverty linkage as it applies to Central America. We do so by using a simple rule of thumb to identify watersheds at greater risk of hydrologically significant land use change: these are watersheds where there is a relatively large interface between agriculture and forest, and where this interface is on a steep slope. For two countries with fine geographic-resolution data on poverty, we assess the overlap between poverty areas and hydrologically sensitive watersheds. For these countries, and the region as whole, we assess the population, area, and biodiversity-relevant forest area contained within hydrologically sensitive watersheds. Since watersheds are nested and exhibit different processes at different scales, we carry out these analyses for watersheds evaluated at different scales. Our attention focuses mostly on watersheds of less than $200 \mathrm{~km}^{2}$, however, because it is within these watersheds that we expect to see the largest relative effect of land use change on hydrological processes.

\section{Hydrological context}

Our analysis is motivated by several ways in which deforestation might degrade hydrological functions and impose risks or costs on people. First, conversion of forest cover to crops or to bare soil is associated with landslides, a serious concern in Central America (PerottoValdiviezo et al in press). Second, loss of forest cover can increase the risk of flooding. There are two mechanisms behind this: total water yield increases (because evapotranspiration is greater for trees than for most other land covers), and infiltration often decreases, in part due to compaction or other soil changes from subsequent land uses. Third, it is possible that deforestation could lead to reductions in dry season flows, if the reduction in infiltration outweighs the increase in water yield. Loss of forest cover can lead to erosion and downslope sedimentation. Finally, loss of cloud forests reduces the 'harvesting' of moisture from fog and clouds, and thus possibly reduces the net supply of water to valleys. (Against this, it should be noted that deforestation elsewhere generally increases total water yield, which can potentially seen as beneficial.) 
The actual impact of deforestation on these hydrological functions depends on soil structure, topography, the nature of the land cover that replaces the forest, and on the spatiotemporal patterns of rainfall. There exist increasingly sophisticated and accurate process-based hydrological models which, when furnished with appropriate biophysical information, can simulate the effect of land cover change on these functions. For the present exercise, however, we focus on simple rules of thumb to identify areas that are might plausibly experience significant hydrological disturbance due to deforestation. It must be understood that these rules of thumb-even when interpreted as 'other things constant'-represent considerable simplifications of complex processes.

The rules of thumb are as follows:

- Risks are greater in smaller watersheds. There is consensus that deforestation can lead to flooding in the smallest watersheds, those under $100 \mathrm{~km}^{2}$ (Kiersch and Tognetti 2002). The strength of the deforestation-flooding relationship in larger basins has been controversial, due to lack of evidence (Chomitz and Kumari 1998; Calder 2000; van Noordwijk, Ranieri, and Tomich 2002). On theoretical grounds, one would expect a milder response of flooding to deforestation in larger basins, due to patchiness of rainfall. As a small storm passes over a large basin, local watersheds experience transient floods, but these even out as individual tributaries merge into the basin's main river. Recent analyses, using process-based hydrological models, suggest that 'far-field' flooding effects of a given proportion of basinwide deforestation may in fact be detectable in basins of at least a few thousand square kilometers, and possibly much larger. (van Noordwijk, Richey, and Thomas 2003). However the impacts of a given absolute area of deforestation clearly are diluted (literally), as measurements are taken farther downstream.

Similarly, the effect of land use change on sedimentation is expected to decline with watershed size, because the sediment has more opportunities to be intercepted and redeposited as the watershed grows. This study takes a conservative approach, focusing on local (within-watershed) hazards of watersheds less than $200 \mathrm{~km}^{2}$ in extent.

- Risks are greater, the larger the proportion of the watershed subject to deforestation. Many of the hydrological changes of interest are closely linked to changes in water yield. The absolute 
increase in water yield is roughly proportional to the area deforested, and hence (holding rainfall constant), so the relative basin-wide impact is related to the proportion deforested. This rule of thumb is rough, though, because the proportional change in basin discharge depends on the level of rainfall. In drier areas, where a larger proportion of incident rainfall is subject to evapotranspiration, the relative effect of deforestation will be greater (van Noordwijk, Richey and Thomas 2003). And, as noted above, hydrological functions other than water yield scale less than proportionally with basin size.

- Risks are greater on steeper slopes. Loss of forest cover on steep slopes is demonstrably related to higher landslide risk (Perotto-Valdiviezo et. al in press) and to greater levels of erosion and sedimentation. To the extent that the loss of infiltration is more severe on deforested slopes than in flat areas, the consequence could be both greater flooding and diminished low-flows.

\section{Biodiversity context}

For the purposes of this study, we rely on a robust rule of thumb relating deforestation to biodiversity: loss of forest habitat is bad for biodiversity. In general, the equilibrium number of supported species declines as a function of habitat area (Brooks Pimm and Oyugi 1999). In areas such as Central America where natural habitat has already been highly fragmented, further habitat loss can result in forest patches too small to maintain viable populations of key species of flora and fauna, leading potentially to an unraveling of the ecosystem. While a more nuanced (and data intensive) study of biodiversity risk might employ information on forest fragmentation and on patterns of species richness and endemism, for present purposes we simply use forest area at risk of conversion to agriculture.

\section{Central American $\underline{\text { Context }}$}

Central America is an apt location for examining forest-poverty-biodiversity linkages. About half its population is classified as poor, and a third of its area is mountainous (table 1). It is particularly rich in biodiversity, with 4,715 endemic plant species and 451 endemic vertebrates (UNDP 1999). It is part of the Mesoamerican biodiversity hotspot (Myers et al 2000), one of 25 places in the world characterized by extremely high plant endemism and high levels of natural habitat loss to date. 
This biodiversity continues to be threatened by land use change. A recent NASA study (Sader et al, n.d.) found annual deforestation rates during the 1990s ranging from 0.16 percent to 1.28 percent in eight Landsat scenes, with a mean of 0.58 percent. A similar sample study by Achard et al (2002) reported annual deforestation rates of 0.8 percent to 1.5 percent.

Guatemala accounts for almost one-third of the population of Central America with a population density second only to El Salvador. Guatemala is amongst the poorest countries in Latin America. Almost 16 percent of the population is extremely poor (i.e. has a per capital annual income of less than \$243.6) and more than half the population is poor (has a per capita annual income less than $\$ 550$.2) (Puri 2002), with the majority living in the central highlands. Forty percent of Guatemala is classed as hilly or mountainous terrain (authors' classification based on Meybeck et al 2001). These areas contain the greatest concentration of upland coniferous forests in Central America.

Honduras is poorer than Guatemala, with gross national income per capita of $\$ 860$. Mountainous regions comprise 61 percent of its territory; forests, 37 percent. Management of hillside agriculture has long been a serious concern for the country, since most of the rural poor live on hillsides and erosion is thought to be high. (Barbier and Bergeron 2001)

\section{Data and methods}

Source data for these analyses (Tables $2 \mathrm{a}, 2 \mathrm{~b}$ and $2 \mathrm{c}$ ) include a number of recently derived digital map products with scales (typically 1:250,000) providing finer spatial resolution than older data.

\section{$\underline{\text { Population }}$}

Guatemala: The 330 Guatemalan municipalities ( $3^{\text {rd }}$ administrative level) are the smallest spatial unit for which data was available. Population data from the National Institute of Statistics (INE) from 1996 was projected to 2000 using historical departmental (2 $2^{\text {nd }}$ administrative level) population growth rates between 1981 and 1994 (figure 1). 
Honduras: The 3730 Honduran aldeas ( $4^{\text {th }}$ administrative level) are the smallest spatial unit for which data was available. Population data from the National Institute of Statistics (INE) was used from 1999 and was projected to 2000 using historical departmental $\left(2^{\text {nd }}\right.$ administrative level) population growth rates between 1974 and 1988.

\section{Poverty}

Guatemala: Municipio-level poverty estimates were constructed by a multi-agency technical team consisting of representatives from SEGEPLAN-INE-URL with technical assistance provided by the World Bank using the method of Elbers, Lanjouw, and Lanjouw (2003). It combines data from the 1994 census and detailed consumption data from a small-sample household budget survey from 1998-99 (ENIGFAM). The survey data is used in regression analyses to calibrate data from the national census, which offers finer spatial detail but less information about consumption. The estimated equation is then applied to the census data (explanatory variables common to the census and the survey) so as to impute consumption levels for all census households. These household-unit imputations are then aggregated to small statistical areas, to obtain more robust estimates of the percentage of households living below the poverty line. The consumption estimates were used to generate estimates of the number of people below the poverty line by municipio (as of 1994).

Honduras: CIAT has produced an aldea-level composite index of basic human needs, combining an educational attainment index (enrollment ratio and adult literacy rate) with a shelter quality index and a health status index (Oyana 1997). The index was used to assign households in four classes of increasing poverty, plus an 'above poverty line' class. Municipios were then assigned to four income classes based on the proportion of households deemed "extremely poor" or "poor":

\begin{tabular}{lllll}
\hline Rank & Definition & \multicolumn{2}{c}{ Proportion extremely poor or poor } \\
\hline 1 & Low & 0 & to & 25 \\
2 & Medium & 25 & to & 50 \\
3 & Severe & 50 & to & 75 \\
4 & Critical & 75 & to & 100 \\
\hline
\end{tabular}




\section{Land $\underline{\text { cover }}$}

The Central American Ecosystems Map (World Bank and CCAD 2001, documented in Vreugdenhil et al 2001) is an adjunct of the Mesoamerican Biological Corridor (MBC) project (UNDP 1999). The map was constructed over 1999-2001, under the auspices of the Comisión Centroamericana de Ambiente y Desarrollo (CCAD). National teams of biologists interpreted satellite images to derive a coordinated and comprehensive set of land cover interpretations. The final version of the map was produced a scale of 1:250,000 and includes approximately 250 ecosystem classes and 15,000 polygons. The map provides fine distinctions on forest cover types, but aggregates all agricultural land covers into a single class $^{1}$. A $100 \mathrm{~m}$ resolution land cover grid (figure 5) was derived from the ecosystem map by reclassifying the 250 ecosystem classes into simple land cover types; montane forest, lowland forest, agriculture, shrub land, wetlands, urban and water.

\section{Topography and watershed delineation}

Topographic data were obtained for Central American countries from a variety of sources. (Table 2c). We generated a 100-meter hydrologically correct elevation surface by interpolating contour lines and spot heights in combination with lakes and rivers data. In turn we identified the rate of maximum change in elevation at each grid cell to generate a slope map.

Watershed boundaries were generated by identifying the direction of steepest descent from each cell, flow direction and surface flow accumulation. Because watersheds are nested, they can be identified at different scales. Our primary interest is in smaller watersheds, but our ability to delineate these watersheds is limited by the resolution of the underlying elevation data and by the scale of the poverty data we wish to relate to watersheds. For Guatemala we identified a set of complete and non-overlapping watersheds with mean area of $200 \mathrm{~km}^{2}$. For Honduras we identified watersheds at three scales with mean areas of 200,100 and $50 \mathrm{~km}^{2}$.

\footnotetext{
${ }^{1}$ Some countries distinguished different degrees of forest disturbance, effectively adding classes that represent agriculture/forest mosaics. However, these classes were not consistent across countries.
} 
Construction of 'critical zones' and measurement of hydrological sensitivity.

As explained earlier, we assume as rough rules of thumb that watershed-level changes in hydrological function are greater, the higher the proportion of the watershed undergoing land cover change, and the greater the proportion of this land cover change on steep slopes. (Clearly many other factors come into play, including soils and precipitation patterns.) We propose a crude indicator of the sensitivity of a watershed's hydrological processes to ongoing land use change, as follows. Grid cells that lay on the interface between forested and agricultural land were identified. This interface was further refined by selecting only those cells which were on slopes of 8 percent (moderately sloping) or greater. A $1 \mathrm{~km}$ buffer region, $500 \mathrm{~m}$ either side of this interface ${ }^{2}$ was defined as the 'critical zone' where upland land cover change between forest and agriculture was most likely to occur (figure 6). This assumption is supported by remote-sensing studies in a variety of locales that show that forest edges face severe deforestation risk (Dawning, Iverson, and Brown 1993; Alves 1999; McConnell Sweeney and Mulley 2004). Finally, we define a watershed's hydrological sensitivity as the ratio of its critical zone area to total area.

\section{Analytic procedures}

For all the analyses, we calculated hydrological sensitivity for sets of watersheds defined at different scales. We calculated watershed forest cover and estimated watershed population (total and, for country-specific analyses, below-poverty-line). Population was allocated from municipios to watersheds on the assumption of constant within-muncipio population densities. This assumption is relatively innocuous where mean watershed size is much larger than mean municipio size, but could introduce errors where municipios encompass or overlap several watersheds ${ }^{3}$. We categorized watersheds by hydrological sensitivity, using a

\footnotetext{
${ }^{2}$ In our classification, shrubland and wetlands were classified as neither agriculture nor forest. Hence shrubland-agriculture and shrubland-forest interfaces were not included in the calculation of critical zones. Since shrublands are most prominent in Honduras (where they account for 7\% of land area), we recomputed the analysis for Honduras shrublands classified as forest. Changes were minor. We chose a symmetric, rather than forest-side only, buffer on the assumption that the forest-agriculture interface may be imprecisely defined where forest-agriculture mosaics exist.

${ }^{3}$ In this case, the assumption of constant population density may tend to overestimate population, and underestimate poverty rates, in steep, forested watersheds. These estimates could be refined using the method of Thomas (2001). This would involve regressing municipio-level poverty data on municipio means of biophysical data (e.g. proportion of municipio in different elevation, slope, or distance-to-road classes). The regression estimate would then be applied to fine-scale gridded data on these regressors to impute poverty across the landscape - say on 2 by $2 \mathrm{~km}$ gridded cells. Finally, this cell level data would be re-aggregated to the watershed level.
} 
nested categorization of watersheds For instance, the category 5 percent + includes all watersheds with at least 5 percent critical area. Figures 1 through 7 show data layer inputs and results for Guatemala, as an example.

\section{Results}

\section{Guatemala}

In Guatemala, there appears to be a strong coincidence between hydrological sensitivity, poverty, and biodiversity for watersheds defined at the $200 \mathrm{~km}^{2}$ scale. Figures 8 and 9 show that many watersheds are characterized by a combination of high poverty rate, high absolute numbers of poor, large absolute areas of montane forest and significant hydrological sensitivity. These relations underlie the tabulations reported in table 3 and figure 10. Watersheds with sensitivity of 10 percent or more contain 70 percent of the nation's poor people and 89 percent of its montane forests. The 77 watersheds with sensitivity of at least 25 percent cover only one sixth of the country's area, but contain a third of its poor people ( 2 million in number) and 42 percent of its montane forest. Average poverty rates increase with sensitivity - from 60 percent poor at 10 percent + sensitivity to 70 percent poor at 25 percent+. More strikingly, the minimum poverty rate increases sharply with increasing sensitivity. No watershed with sensitivity greater than 25 percent has a poverty rate below 40 percent.

\section{$\underline{\text { Honduras }}$}

The nexus is qualitatively similar though less pronounced in Honduras, and intensifies when the analysis is conducted for smaller watersheds. (Keep in mind that the Honduran poverty definitions are not comparable to those of Guatemala.) Looking at watersheds with mean area of about $200 \mathrm{~km}^{2}$, poverty rates are relatively constant across sensitivity classes 0 percent + through 20 percent + (figure 11). Poverty rates are markedly higher for the few watersheds in the 25 percent + sensitivity category, but there are very few such watersheds at this scale. Hence, at this scale, the poor are not significantly concentrated in the most sensitive watersheds. Similarly, montane forests are not concentrated in the highest sensitivity classes and indeed are overrepresented in the lowest sensitivity classes. Nonetheless, there is overlap among poverty, forest cover and hydrological sensitivity. Watersheds with hydrological sensitivity of 10 percent or more contain about half of the country's poor people, and 58 percent of its montane forest Watersheds with 20 percent+ 
sensitivity contain 10 percent of Honduras's poor and 15 percent of its montane forest. In contrast to Guatemala, few watersheds at the $200 \mathrm{~km}^{2}$ scale have sensitivity levels above 20 percent.

These results are themselves sensitive to the scale of the watershed being considered. Figure 12 repeats figure 11, but is calculated for watersheds with mean size of about $50 \mathrm{~km}^{2}$. Focusing at this scale reveals that the sensitivity of some small-scale watersheds is obscured when they are aggregated into larger ones. Thus the area of sensitivity 20 percent+ watersheds is substantially greater when smaller watersheds are considered. At the $50 \mathrm{~km}^{2}$ scale, watersheds with 20 percent+ sensitivity contain 17 percent of the country's poor people and 25 percent of its montane forest.

\section{Central America}

Finally, table 4 shows, for Central America as a whole, the effect of calculating hydrological sensitivity for watersheds of different scales. The largest-scale watersheds are not very sensitive, by our measure. None of the 13 watersheds in the $20,000 \mathrm{~km}^{2}$ class have sensitivity levels of 20 percent or higher. However, at the $2000 \mathrm{~km}^{2}$ scale, there are 17 such watersheds, together comprising $33,000 \mathrm{~km}^{2}$ and containing 4.7 million people. And at the $50 \mathrm{~km}^{2}$ scale, watersheds with sensitivity of 20 percent or more account for 121,000 $\mathrm{km}^{2}$ and over 13 million people. Figure 13 shows these watersheds, which are predominantly located in Guatemala, Honduras, and Costa Rica. Other areas of Central America fail to meet our sensitivity criteria, based on available data.

\section{Discussion and conclusions}

The analysis directs attention to natural resource management in small (less than $200 \mathrm{~km}^{2}$ or even less than $50 \mathrm{~km}^{2}$ ) watersheds. It is in these small watersheds that the relative scale and rapidity of land cover change is likely to be large. That is, it is presumably more likely that a $50 \mathrm{~km}^{2}$ watershed could lose half its forest cover in a decade than a 5,000 km ${ }^{2}$ watershed. Moreover, watersheds of this size are likely to exhibit larger changes in hydrological behavior (aside from total water yield) for a given change in land cover than larger ones. Finally, it may be easier to organize residents of a small watershed for collective action. 
The analysis suggests that indeed there are localized nexi where poverty, biodiversity, and hydrology concerns are likely to coincide. Guatemala emerges, in particular, as a place where poverty, biodiversity threats, and hydrological sensitivity may be concentrated in small watersheds. In Honduras, there is also a significant poverty-biodiversity-hydrology nexus, though the overlap is not as marked as in Guatemala. Hydrologically sensitive areas (by this definition) are found in much of Costa Rica and in some sections of El Salvador and Nicaragua.

This analysis can suggest geographical priorities for attention to the poverty-biodiversityhydrology nexus. But the coincidence of these three concerns doesn't necessarily mean that a single policy prescription can address all three. Key questions for in-depth diagnosis might include:

- Who is responsible for deforestation, and what economic or other incentives drive deforestation?

- If forest is being converted to agriculture, what are the hydrological properties of the transformed landscape?

- Who is exposed to the potential negative hydrological impacts of deforestation?

Careful diagnosis will suggest whether the three problems - biodiversity loss, poverty, and hydrological disturbance - can be addressed by a single policy, or will require two or even three distinct responses. For instance, conversion of native forest to agroforestry may help to alleviate poverty without negative hydrological effects, but could hurt biodiversity. (van Noordwijk, Richey and Thomas 2003). Conservation of native forests could stabilize hydrology and conserve biodiversity, but poor downslope beneficiaries of hydrological services may be unable to compensate (possibly wealthier) upslope farmers for refraining from deforestation.

\section{Limitations of the analysis and directions for further work}

The heuristic analyses presented here rest on a number of assumptions and cannot substitute for rigorous hydrological modeling. In particular, the analysis does not take account of: 
- Actual deforestation rates and locations, which may not coincide with the forestagriculture-hillside interface

- Differential hydrological effects of different kinds of natural and agricultural land covers, and of different soil types

- Spatial variation in precipitation

- Issues related to water quality, especially the impact of pollution and sedimentation on freshwater and marine biodiversity

- Biodiversity characteristics, including endemism and habitat fragmentation

Therefore our focus on small basins, and our designation of 'sensitive' watersheds, is far from definitive. It does not rule out the possibility of significant hydrology-biodiversityeconomy linkages in other locales and at other scales. For instance, hillside management of coffee in El Salvador may have important hydrological and biodiversity implications. Forest and wetlands maintenance in the flat lowlands may be crucial for groundwater recharge, flood buffering, and water quality. And the impact of sediment and chemical pollution on Atlantic coral reefs is a serious concern.

Nor does the analysis entirely rule out the potential for 'far-field' effects -notably the possibility that upland deforestation might affect water quality or flooding risk in lower-basin urban areas. This is particularly plausible when cities are located in small, steep watersheds. It is of particular interest because the urban population may have a large willingness to pay for watershed maintenance. Identification of far-field effects would however require the application of a process-based hydrological model such as VIC or DHSVM (van Noordwijk, Richey, and Thomas 2003).

Finally, improved topographical data for Central America are now becoming available thanks to the SRTM (shuttle radar topography mission). This, together with new census data and better measurement of deforestation rates, will permit improved identification of hydrological risks. 
Nonetheless, we believe that the current analysis is useful, given that rigorous hydrological modeling is complex and data-intensive. This analysis may guide future modeling and data collection efforts and serve as an interim resource for policy formulation. 


\section{References}

Achard F., H. D. Eva, H.-J. Stibig, P. Mayaux., J. Gallego, T. Richards, and J.-P. Malingreau. 2002. "Determination of Deforestation Rates of the World's Human Tropical Forests." Science 297: 999-1002.

Alves, Diógenes. 1999. "An Analysis of the Geographical Patterns of Deforestation in Brazilian Amazônia in the 1991-1996 Period.” Prepared for the Conference on Patterns and Processes of Land Use and Forest Change in the Amazon, Center for Latin American Studies, University of Florida, March 23-26.

Barbier, Bruno, and Giles Bergeron. 2001. "Natural Resource Management in the Hillsides of Honduras: Bioeconomic Modeling at the Microwatershed Level." International Food Policy Research Institute, Research Report 123.

Brooks, T. M., S. L. Pimm, and J.O. Oyugi. 1999. “Time Lag between Deforestation and Bird Extinction in Tropical Forest Fragments." Conservation Biology 13: 1140-50.

Calder, Ian. 2000. "Land Use Impacts on Water Resources." Rome: FAO Land-Water Linkages in Rural Watersheds, Background Paper no. 1.

Chomitz, Kenneth M., and Kanta Kumari. 1998. "The Domestic Benefits of Forests: A Critical Review." World Bank Research Observer 13(1): 13-35.

Chomitz, Kenneth M., Esteban Brenes, and Luis Constantino. 1999 "Financing Environmental Services: The Costa Rican Experience and its Implications." The Science of the Total Environment 240: 157-69.

Dawning, S. Liu, Louis R. Iverson, and Sandra Brown. 1993. "Rates and Patterns of Deforestation in the Philippines: Application of Geographic Information System Analysis. Forest Ecology and Management 57: 1-16. 
Echavarría, Marta. 2001. "Water User Associations in the Cauca Valley, Colombia: A Voluntary Mechanism to Promote Upstream-Downstream Cooperation in the Protection of Rural Watersheds." Rome: FAO Land-Water Linkages in Rural Watersheds Case Study Series.

Elbers, C., J. O. Lanjouw, and P. Lanjouw. 2003. "Micro-Level Estimation of Poverty and Inequality.” Econometrica 71: 355-64.

Johnson, Nels, Andy White, and Danièle Perrot-Maitre. 2001. "Developing Markets for Water Services from Forests: Issues and Lessons from Innovators.” Washington DC: Forest Trends.

Kiersch, Benjamin, and Sylvia Tognetti. 2002. "Land-Water Linkages in Rural Watersheds: Results from the FAO Electronic Workshop.” Land and Water Resources 2(1): 1-1.6

McConnell, W. J., S. P. Sweeney, and B. Mulley. 2004. "Physical and Social Access to Land: Spatio-Temporal Patterns of Agricultural Expansion in Madagascar." Agriculture Ecosystems and Environment 101: 171-84.

Myers, N, R. A. Mittermeier, C. Mittermeier, G. A. B. da Fonseca, and J. Kent. 2000. “Biodiversity Hotspots for Conservation Priorities.” Science 403: 853-58.

Pagiola, Stefano, Joshua Bishop, and Natasha Landell-Mills. 2002. Selling Forest Environmental Services: Market-based Mechanisms for Conservation and Development. London: Earthscan.

Sader, Steven A.., Daniel J. Hayes, Daniel E. Irwin, and Sasan S. Saatchi. n.d. "Preliminary Forest Change Estimates for Central America (1990s), with reference to the proposed Mesoamerican Biological Corridor,” accessed October 2002. http://www.ghcc.msfc.nasa.gov/corredor/corredor publications.html

UNDP (United Nations Development Programme). 1999. Establishment of a Programme for the Consolidation of the Mesoamerican Biological Corridor: Project Document. 
van Noordwijk, Meine, Simone Ranieri, and Tom Tomich. 2001. "Scale Effects of Land Cover Change on Watershed Functions in the Humid Tropics." Paper prepared for Functional Value of Biodiversity Project, Development Research Group, World Bank.

van Noordwijk, Meine, Jeffrey Richey, and David Thomas, with others. 2003. "Functional Value of Biodiversity Project, Technical Report for Activity 2." Prepared for Development Research Group, World Bank.

Vreugdenhil, Daan, Jan Meerman, Alain Meyrat, Luis Diego Gómez, and Douglas J. Graham. 2002. Map of the Ecosystems of Central America: Final Report. Washington, D.C.: World Bank.

World Bank and CCAD. 2001. "Ecosystems of Central America (ArcView regional map files at 1:250,000)." World Bank, Comisión Centroamericana de Ambiente y Desarrollo (CCAD), World Institute for Conservation and Environment (WICE), and the Centro Agronómico Tropical de Investigación y Enseñanza (CATIE), Washington, D.C. (http://www.worldbank.org/ca-env). 


\section{Acknowledgements}

Spatial datasets, census information and surveys generously provided by the following agencies. Any errors of use or interpretation are the authors'.
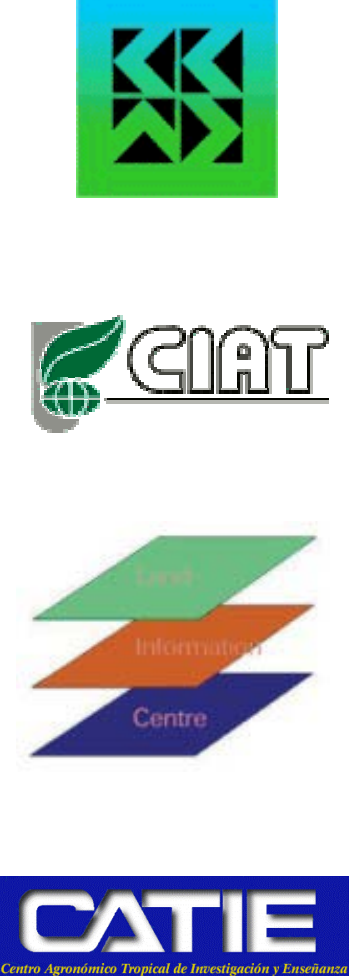

Central American Commission for Environment and Development

Comisión Centroamericana de Ambiente y Desarrollo

http://ccad.sgsica.org

International Centre for Tropical Agriculture

Centro Internacional de Agricultura Tropical

http://www.ciat.cgiar.org

Land Information Center, Belize

Centro de Información Territorial
Tropical Agricultural Research Center, Costa Rica

Centro Agronómico Tropical de Investigación

http://www.catie.ac.cr/catie/

National Registry Center, El Salvador

Centro Nacional de Registros

http://www.cnr.gob.sv/ign/ign2000.htm

Ministry for the Environment and Natural Resources, El Salvador

Ministerio de Medio Ambiente y Recursos Naturales

http://www.marn.gob.sv

National Geographic Institute, Guatemala

$\underline{\text { Instituto Geográfico Nacional }}$

http://www.ign.gob.gt 


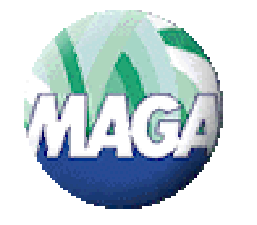
Ministry of Agriculture, Guatemala
Ministerio de Agricultura, Ganadería y Alimentación
http://www.maga.gob.gt

Secretariat of Planning and Programming, Guatemala

PLANFICACIONYPROCRAMACION
SECE E L A N

Panicaclon r RoumancloN Secretaría de Planificación y Programación de la Presidencia

http://www.segeplan.gob.gt

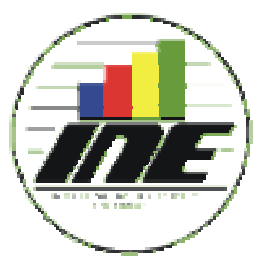

National Institute of Statistics, Guatemala

Instituto Nacional de Estadística

http://www.ine.gob.gt
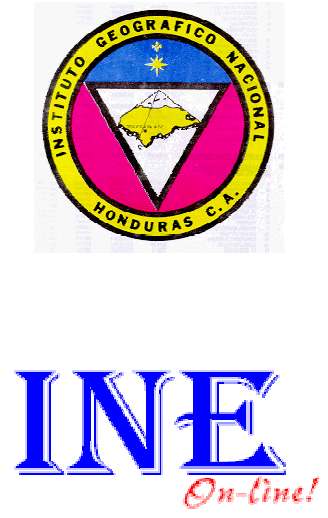

National Institute of Statistics, Honduras

Instituto Nacional de Estadística

http://www.ine.online.hn/

Ministry of Natural Resources and the Environment, Honduras

Secretaría de Recursos Naturales y Ambiente

http://www.serna.gob.hn/

GeOdigital, Nicaragua

http://www.geocities.com/geodigital2001/Principal.htm

Social Investment Fund, Panama

Fondo de Inversion Social

http://www.fis.gob.pa 
Table 1. Selected country level statistics for Central America, data sources in parentheses.

\begin{tabular}{|c|c|c|c|c|c|c|c|c|c|c|c|}
\hline \multirow[t]{2}{*}{ Country } & \multirow{2}{*}{$\begin{array}{c}\text { Area } \\
(\text { CIAT) } \\
\mathrm{km}^{2}\end{array}$} & \multicolumn{2}{|c|}{$\begin{array}{c}\text { Population } \\
\text { (CIAT) }\end{array}$} & \multicolumn{2}{|c|}{$\begin{array}{l}\text { Population below } \\
\text { poverty line } \\
\text { (WDI) }\end{array}$} & \multicolumn{2}{|c|}{$\begin{array}{c}\text { Forest area } \\
\text { (CCAD) }\end{array}$} & \multicolumn{2}{|c|}{$\begin{array}{c}\text { Mountainous area } \\
\text { (authors } \\
\text { calculations) }\end{array}$} & \multicolumn{2}{|c|}{$\begin{array}{c}\text { Montane } \\
\text { forest area } \\
\text { (authors } \\
\text { calculations) }\end{array}$} \\
\hline & & millions & per $\mathrm{km}^{2}$ & millions & As $\%$ & $\mathrm{~km}^{2}$ & As $\%$ & $\mathrm{~km}^{2}$ & As $\%$ & $\mathrm{~km}^{2}$ & As $\%$ \\
\hline Belize & 23,000 & 0.24 & 11.2 & 0.1 & 33 & 12,000 & 50 & 3,000 & 13 & 3,000 & 12 \\
\hline Costa Rica & 51,000 & 3.7 & 71.5 & 0.8 & 21 & 13,000 & 26 & 22,000 & 43 & 10,000 & 19 \\
\hline El Salvador & 21,000 & 6.1 & 303 & 2.9 & 48 & 2,500 & 11 & 9,000 & 43 & 1,500 & 7 \\
\hline Guatemala & 109,000 & 11.4 & 105 & 6.8 & 60 & 45,000 & 42 & 45,000 & 41 & 22,000 & 20 \\
\hline Honduras & 112,000 & 6.5 & 58 & 3.5 & 53 & 41,000 & 37 & 68,000 & 61 & 30,000 & 27 \\
\hline Nicaragua & 130,000 & 5 & 41.5 & 2.5 & 50 & 39,000 & 30 & 18,000 & 14 & 6,000 & 5 \\
\hline Panama & 76,000 & 2.9 & 38.4 & 1.1 & 37 & 42,000 & 55 & 19,000 & 25 & 14,000 & 19 \\
\hline Central America & 522,000 & 36 & 69 & 18 & 49 & 195,000 & 37 & 184,000 & 35 & 86,000 & 17 \\
\hline
\end{tabular}


Table 2a. Available spatial datasets for Guatemala.

\begin{tabular}{l|ccl}
\hline \multicolumn{1}{c|}{ Data } & Scale & Year & \multicolumn{1}{c}{ Sources and comments } \\
\hline Population & NA. & 2000 (est.) & CIAT. Municipal level data. \\
Poverty rates & NA & $1998-1999$ & SEGEPLAN, INE and World Bank. Municipal level data. \\
Municipal boundaries & $1: 250,000$ & 1996 & MAGA and IGN. \\
Elevation & $1: 250,000$ & 2002 & 100m grid derived by authors from 100m contours (MAGA, IGN). \\
Slope & $1: 250,000$ & 2002 & Slope in percent derived by authors from elevation data. \\
Watershed boundaries & $1: 250,000$ & 2002 & Avg. area= 180km², derived by authors from elevation data. \\
Land cover & $1: 250,000$ & $1999-2000$ & CCAD, classification derived by authors from 200+ ecosystems. \\
Rivers & $1: 250,000$ & 1996 & MAGA and IGN. \\
Lakes & $1: 250,000$ & 1996 & MAGA and IGN. \\
\hline
\end{tabular}


Table 2b. Available spatial datasets for Honduras.

\begin{tabular}{l|ccl}
\hline \multicolumn{1}{c|}{ Data } & Scale & Year & \multicolumn{1}{c}{ Sources and comments } \\
\hline Population & NA. & 2000 (est.) & CIAT. Municipal level data. \\
Poverty rates & NA & $1998-1999$ & CIAT. Municipal level data. \\
Aldea boundaries & $1: 50,000$ & 1999 & SERNA. \\
Elevation & $1: 50,000$ & 2002 & 100m grid derived by authors from 100m contours (CIAT). \\
Slope & $1: 50,000$ & 2002 & Slope in percent derived by authors from elevation data. \\
Watershed boundaries & $1: 50,000$ & 2002 & Avg. area $=180 \mathrm{~km}$, derived by authors from elevation data. \\
Land cover & $1: 250,000$ & $1999-2000$ & CCAD, classification derived by authors from 200+ ecosystems. \\
Rivers & $1: 50,000$ & 1996 & CIAT. \\
Lakes & $1: 50,000$ & 1996 & CIAT. \\
\hline
\end{tabular}


Table 2c. Available spatial datasets for Central America.

\begin{tabular}{l|ccl}
\hline \multicolumn{1}{c|}{ Data } & Scale & Year & \multicolumn{1}{c}{ Sources and comments } \\
\hline Population & NA. & 2000 (est.) & CIAT. Municipal level data. \\
Municipal boundaries & $1: 250,000$ & 2000 & CIAT. \\
Elevation & $1: 250,000$ & 2002 & (Various sources*) $100 \mathrm{~m}$ grid derived by authors from 100m contours \\
Slope & $1: 250,000$ & 2002 & Slope in percent derived by authors from elevation data. \\
Watershed boundaries & $1: 250,000$ & 2002 & 9 level hierarchy derived by authors from elevation data. \\
Land cover & $1: 250,000$ & $1999-2000$ & CCAD, classification derived by authors from 200+ ecosystems. \\
Rivers & $1: 250,000$ & 2002 & Various sources*. \\
Lakes & $1: 250,000$ & 2002 & Various sources*. \\
\hline
\end{tabular}

Belize - CIAT

Guatemala - MAGA and IGN

El Salvador - MARN and CNR

Honduras - CIAT, IGN and SERNA

Nicaragua - GeOdigital

Costa Rica - CATIE

Panama - FIS 
Table 3. Population, poverty and forest statistics according to watershed sensitivity class for Guatemala (note: classes are nested)

\begin{tabular}{|c|c|c|c|c|c|c|c|c|c|c|c|c|c|}
\hline \multirow{2}{*}{$\begin{array}{l}\text { Watersheds } \\
\text { classified by } \\
\text { hydrological } \\
\text { sensitivity } \\
\text { (critical } \\
\text { zone/watershed } \\
\text { area) }\end{array}$} & \multicolumn{2}{|c|}{$\begin{array}{l}\text { Number of } \\
\text { watersheds }\end{array}$} & \multicolumn{2}{|c|}{ Area } & Populatior & \multicolumn{2}{|c|}{$\begin{array}{l}\text { Poverty } \\
\text { rate }\end{array}$} & \multicolumn{2}{|l|}{$\begin{array}{c}\text { Poor } \\
\text { people }\end{array}$} & \multicolumn{2}{|c|}{$\begin{array}{c}\text { Forest } \\
\text { area }\end{array}$} & \multicolumn{2}{|r|}{$\begin{array}{l}\text { Montane } \\
\text { forest area }\end{array}$} \\
\hline & Count & $\begin{array}{c}\text { As } \% \text { of } \\
\text { national total }\end{array}$ & $\mathrm{Km}^{2}$ & $\begin{array}{c}\text { As } \% \text { of } \\
\text { nationa } \\
1 \text { total }\end{array}$ & '000 & As $\%$ & ‘000 & $\begin{array}{c}\text { As } \% \text { of } \\
\text { total } \\
\text { national } \\
\text { poor }\end{array}$ & $\begin{array}{c}\text { As } \% \text { of } \\
\text { total } \\
\text { national } \\
\text { pop. }\end{array}$ & $\mathrm{Km}^{2}$ & $\begin{array}{c}\text { As } \% \text { of } \\
\text { national } \\
\text { total } \\
\text { forest }\end{array}$ & $\mathrm{Km}^{2}$ & $\begin{array}{c}\text { As } \% \text { of national } \\
\text { total montane } \\
\text { forest }\end{array}$ \\
\hline Any percentage & 562 & $100 \%$ & 102,790 & $100 \%$ & 11,000 & $53 \%$ & 5,900 & $100 \%$ & $53 \%$ & 44,002 & $100 \%$ & 11,165 & $100 \%$ \\
\hline $5 \%+$ & 253 & $45 \%$ & 55,896 & $54 \%$ & 7,700 & $60 \%$ & 4,600 & $79 \%$ & $42 \%$ & 23,805 & $54 \%$ & 10,763 & $96 \%$ \\
\hline $10 \%+$ & 197 & $35 \%$ & 43,996 & $43 \%$ & 6,900 & $60 \%$ & 4,100 & $70 \%$ & $37 \%$ & 19,491 & $44 \%$ & 9,929 & $89 \%$ \\
\hline $15 \%+$ & 149 & $27 \%$ & 33,136 & $32 \%$ & 5,000 & $68 \%$ & 3,400 & $58 \%$ & $31 \%$ & 14,566 & $33 \%$ & 8,148 & $73 \%$ \\
\hline $20 \%+$ & 106 & $19 \%$ & 22,404 & $22 \%$ & 3,700 & $69 \%$ & 2,500 & $43 \%$ & $23 \%$ & 10,214 & $23 \%$ & 6,020 & $54 \%$ \\
\hline $25 \%+$ & 77 & $14 \%$ & 16,893 & $16 \%$ & 2,900 & $70 \%$ & 2,000 & $34 \%$ & $18 \%$ & 7,553 & $17 \%$ & 4,709 & $42 \%$ \\
\hline $30 \%+$ & 48 & $9 \%$ & 9,325 & $9 \%$ & 1,700 & $73 \%$ & 1,200 & $21 \%$ & $11 \%$ & 4,241 & $10 \%$ & 2,989 & $27 \%$ \\
\hline $35 \%+$ & 23 & $4 \%$ & 3,558 & $3 \%$ & 800 & $75 \%$ & 600 & $10 \%$ & $5 \%$ & 1,653 & $4 \%$ & 1,270 & $11 \%$ \\
\hline $40 \%+$ & 14 & $2 \%$ & 1,853 & $2 \%$ & 70 & $80 \%$ & 300 & $5 \%$ & $3 \%$ & 849 & $2 \%$ & 676 & $6 \%$ \\
\hline
\end{tabular}


Table 4. Central American watersheds classified by scale and sensitivity

\begin{tabular}{|c|c|c|c|c|c|c|c|c|c|}
\hline \multicolumn{10}{|c|}{ Critical zone area by scale and sensitivity } \\
\hline \multirow{2}{*}{$\begin{array}{c}\text { Sensitivity } \\
\%\end{array}$} & \multicolumn{9}{|c|}{ Watershed scale $\left(\mathrm{km}^{2}\right)$} \\
\hline & 20,000 & 10,000 & 5,000 & 2,000 & 1,000 & 500 & 200 & 100 & 50 \\
\hline 0 & 16,354 & 20,674 & 22,050 & 27,506 & 28,660 & 29,653 & 30,792 & 31,510 & 32,003 \\
\hline 5 & 13,199 & 17,998 & 19,141 & 24,567 & 25,843 & 27,103 & 28,436 & 29,639 & 30,510 \\
\hline 10 & 11,465 & 14,676 & 14,469 & 19,743 & 21,428 & 22,325 & 23,972 & 25,561 & 27,187 \\
\hline 15 & 4,561 & 6,652 & 8,616 & 11,228 & 12,915 & 14,924 & 18,328 & 20,264 & 22,625 \\
\hline 20 & - & 1,163 & 1,163 & 4,750 & 7,348 & 9,432 & 12,198 & 15,208 & 17,857 \\
\hline 25 & - & - & - & 2,824 & 3,560 & 5,233 & 7,850 & 10,563 & 13,488 \\
\hline 30 & - & - & - & 975 & 1,748 & 2,715 & 4,673 & 7,188 & 9,345 \\
\hline 35 & - & - & - & - & 278 & 844 & 2,280 & 3,957 & 6,287 \\
\hline 40 & - & - & - & - & 278 & 278 & 1,465 & 2,391 & 4,207 \\
\hline 50 & - & - & - & - & - & - & 253 & 612 & 1,228 \\
\hline
\end{tabular}

\begin{tabular}{|c|c|c|c|c|c|c|c|c|c|}
\hline \multicolumn{10}{|c|}{ Total watershed population ('000) by scale and sensitivity } \\
\hline$\%$ & 20,000 & 10,000 & 5,000 & 2,000 & 1,000 & 500 & 200 & 100 & 50 \\
\hline 0 & 16,700 & 19,023 & 21,312 & 28,470 & 29,568 & 30,544 & 32,339 & 33,114 & 33,602 \\
\hline 5 & 12,223 & 14,862 & 16,497 & 22,612 & 21,642 & 19,759 & 17,169 & 17,335 & 15,673 \\
\hline 10 & 7,936 & 7,834 & 7,877 & 12,325 & 14,650 & 12,462 & 12,642 & 11,857 & 11,199 \\
\hline 15 & 4,302 & 4,953 & 5,379 & 7,216 & 7,831 & 7,870 & 7,843 & 8,319 & 8,423 \\
\hline 20 & - & 460 & 460 & 2,372 & 3,114 & 4,201 & 4,781 & 5,639 & 6,070 \\
\hline 25 & - & - & - & 1,843 & 1,701 & 2,594 & 3,261 & 4,037 & 4,309 \\
\hline 30 & - & - & - & 528 & 632 & 1,034 & 1,819 & 2,648 & 2,734 \\
\hline 35 & - & - & - & - & 29 & 215 & 884 & 1,437 & 1,769 \\
\hline 40 & - & - & - & - & 29 & 29 & 387 & 555 & 1,030 \\
\hline 50 & - & - & - & - & - & - & 56 & 133 & 299 \\
\hline
\end{tabular}


Table 4 (cont). Central American watersheds classified by scale and sensitivity

\begin{tabular}{|c|c|c|c|c|c|c|c|c|c|}
\hline \multicolumn{10}{|c|}{ Number of watersheds by scale and sensitivity } \\
\hline$\%$ & 20,000 & 10,000 & 5,000 & 2,000 & 1,000 & 500 & 200 & 100 & 50 \\
\hline $\mathbf{0}$ & 13 & 28 & 65 & 202 & 428 & 628 & 1,448 & 2,714 & 4,585 \\
\hline 5 & 6 & 14 & 30 & 87 & 166 & 349 & 866 & 1,784 & 3,270 \\
\hline 10 & 5 & 10 & 17 & 55 & 108 & 230 & 589 & 1,256 & 2,467 \\
\hline 15 & 2 & 4 & 8 & 27 & 56 & 126 & 375 & 845 & 1,782 \\
\hline 20 & - & 1 & 1 & 10 & 26 & 71 & 215 & 566 & 1,247 \\
\hline 25 & - & - & - & 5 & 12 & 34 & 122 & 373 & 866 \\
\hline 30 & - & - & - & 2 & 5 & 16 & 68 & 230 & 556 \\
\hline 35 & - & - & - & - & 1 & 5 & 34 & 135 & 365 \\
\hline 40 & - & - & - & - & 1 & 1 & 21 & 84 & 238 \\
\hline 50 & - & - & - & - & - & - & 5 & 27 & 80 \\
\hline
\end{tabular}

\begin{tabular}{|c|c|c|c|c|c|c|c|c|c|}
\hline \multicolumn{10}{|c|}{ Total watershed area by scale and sensitivity } \\
\hline$\%$ & 20,000 & 10,000 & 5,000 & 2,000 & 1,000 & 500 & 200 & 100 & 50 \\
\hline 0 & 228,826 & 277,723 & 318,689 & 387,585 & 412,940 & 438,206 & 461,753 & 475,147 & 483,437 \\
\hline 5 & 105,991 & 142,291 & 155,447 & 191,321 & 191,226 & 193,550 & 185,847 & 178,835 & 167,899 \\
\hline 10 & 87,604 & 105,229 & 95,440 & 125,007 & 131,583 & 127,109 & 124,758 & 123,960 & 122,600 \\
\hline 15 & 27,418 & 37,969 & 47,826 & 56,000 & 62,366 & 68,560 & 79,220 & 81,590 & 85,879 \\
\hline 20 & - & 5,397 & 5,397 & 19,514 & 29,570 & 36,443 & 43,999 & 52,506 & 58,601 \\
\hline 25 & - & - & - & 10,339 & 12,127 & 17,270 & 24,577 & 31,747 & 38,981 \\
\hline 30 & - & - & - & 3,179 & 5,297 & 7,966 & 12,958 & 19,455 & 23,953 \\
\hline 35 & - & - & - & - & 585 & 2,128 & 5,477 & 9,366 & 14,461 \\
\hline 40 & - & - & - & - & 585 & 585 & 3,233 & 5,153 & 8,895 \\
\hline 50 & - & - & - & - & - & - & 463 & 1,122 & 2,165 \\
\hline
\end{tabular}




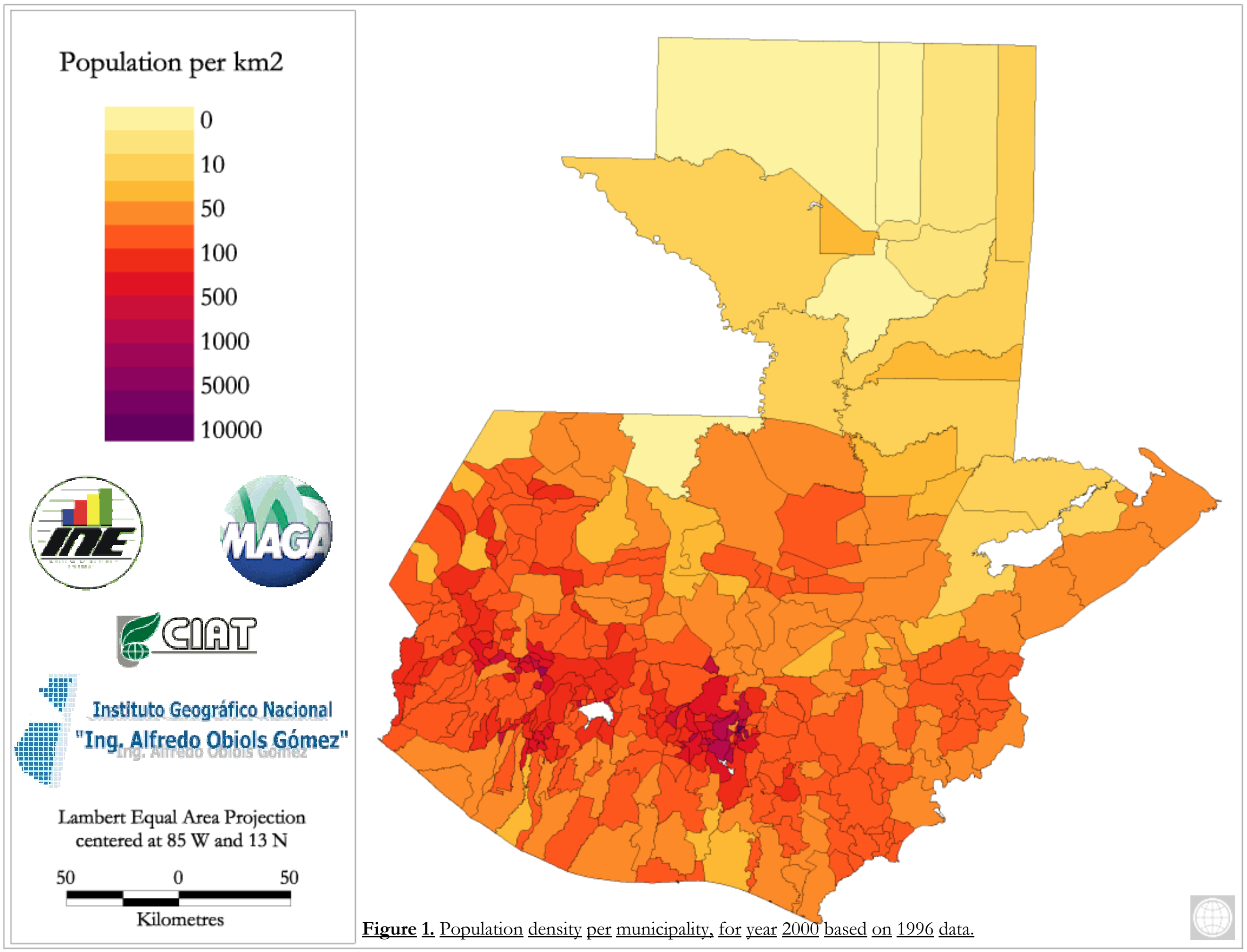




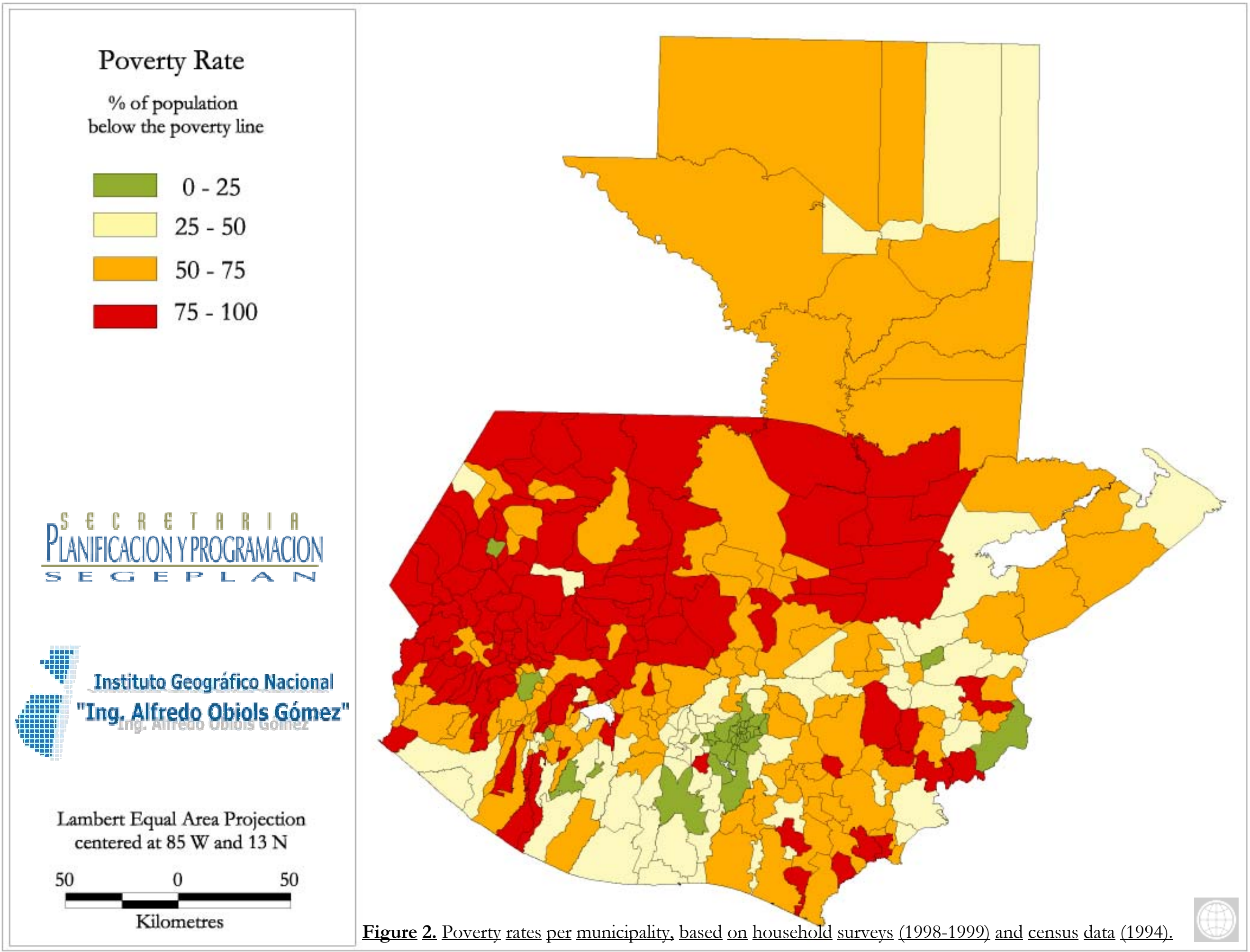




\section{Slope in percent}

0
1
5
10
25
40
75
$100+$

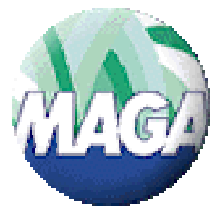

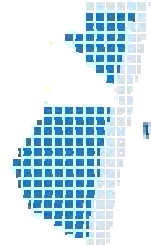

Instituto Geográfico Nacional "Ing. Alfredo Obiols Gómez"

Lambert Equal Area Projection centered at $85 \mathrm{~W}$ and $13 \mathrm{~N}$

50 0 50

Kilometres

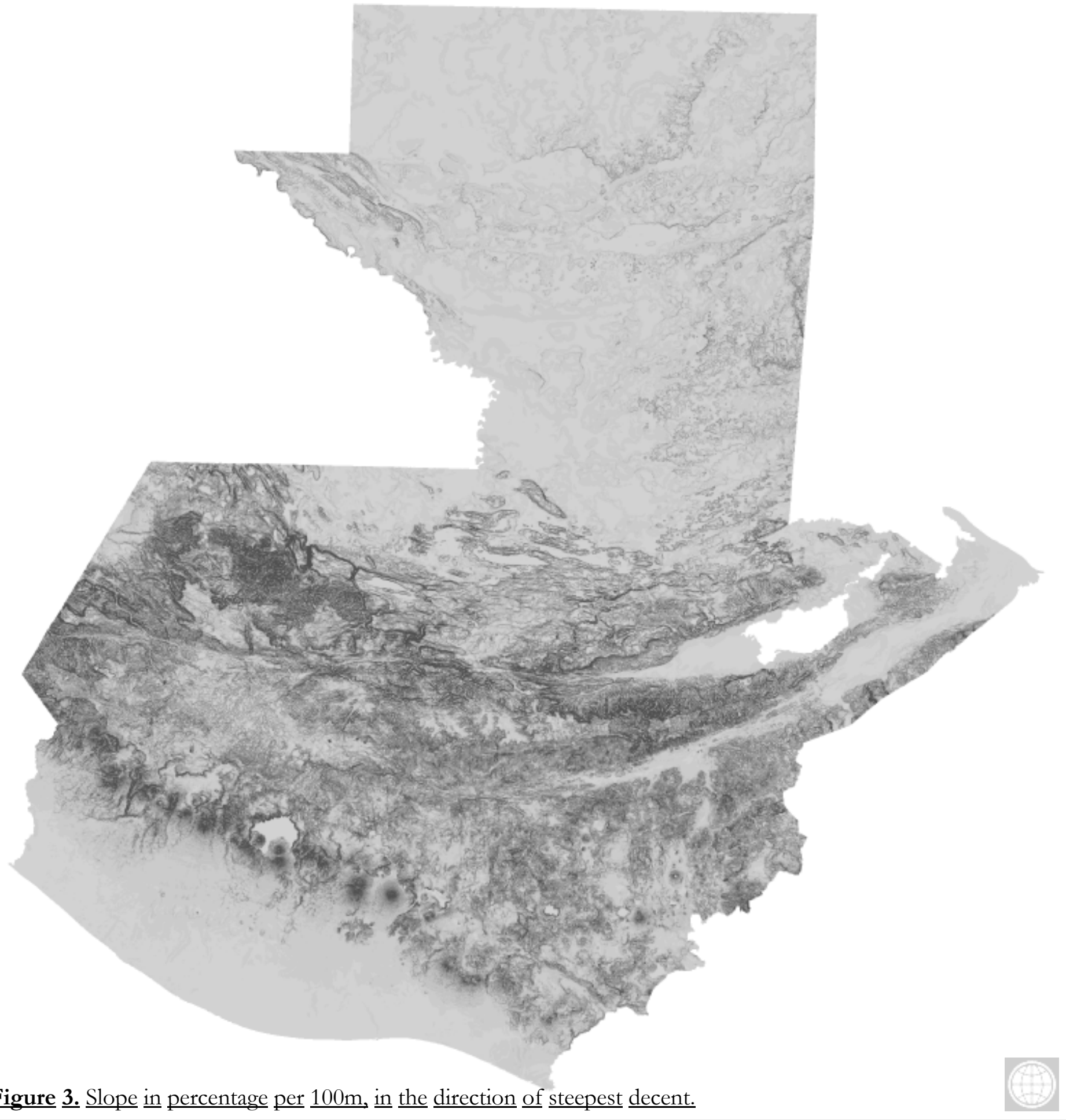


Watersheds and elevation (m)

0
100
250
500
1000
2000
3000
4000
5000

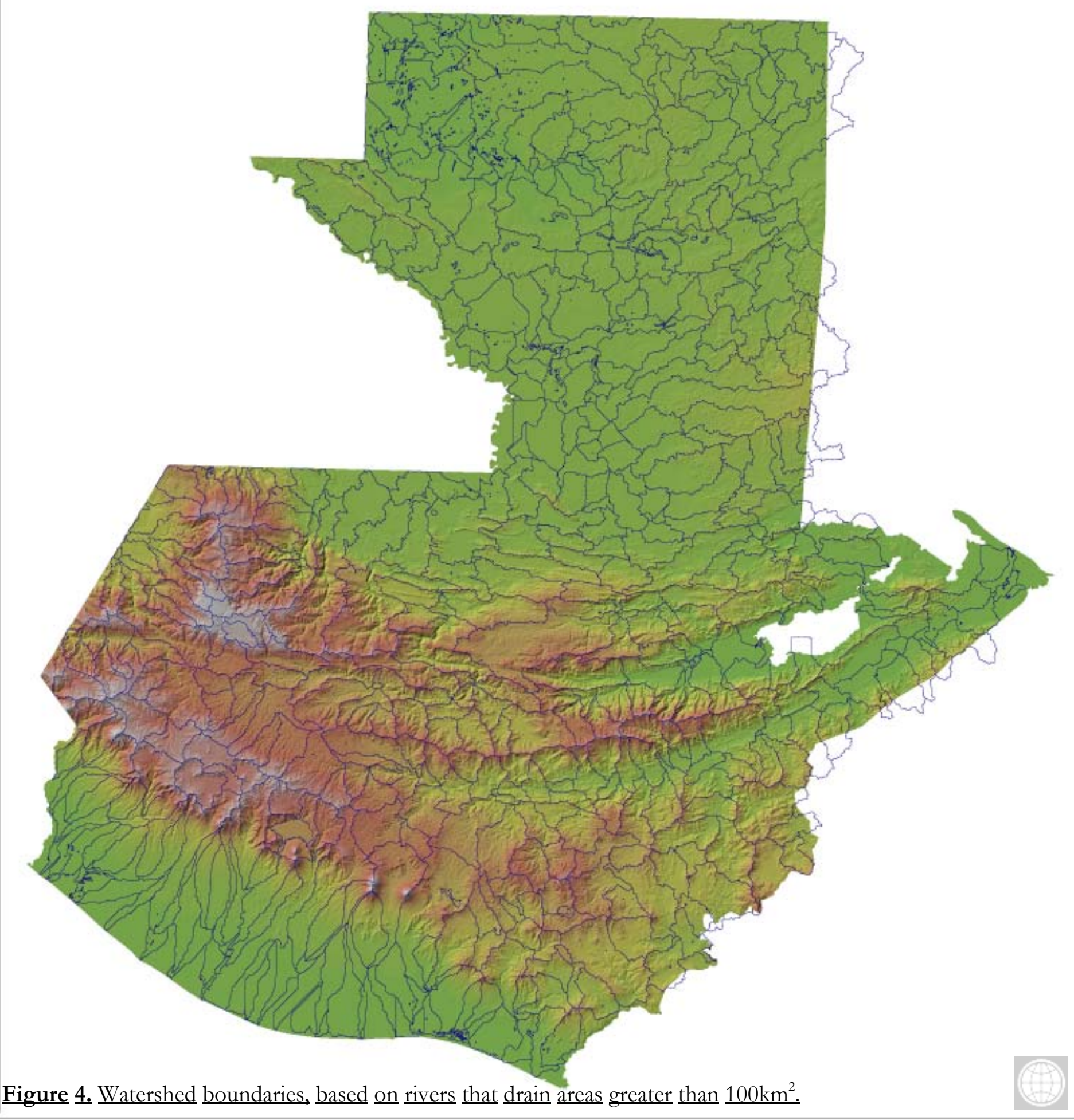




\section{Land Cover}

simplified land classes

\section{Agriculture}

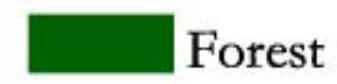

Wetlands

Other Veg.

Urban

\section{乘}

Lambert Equal Area Projection centered at $85 \mathrm{~W}$ and $13 \mathrm{~N}$

50 50

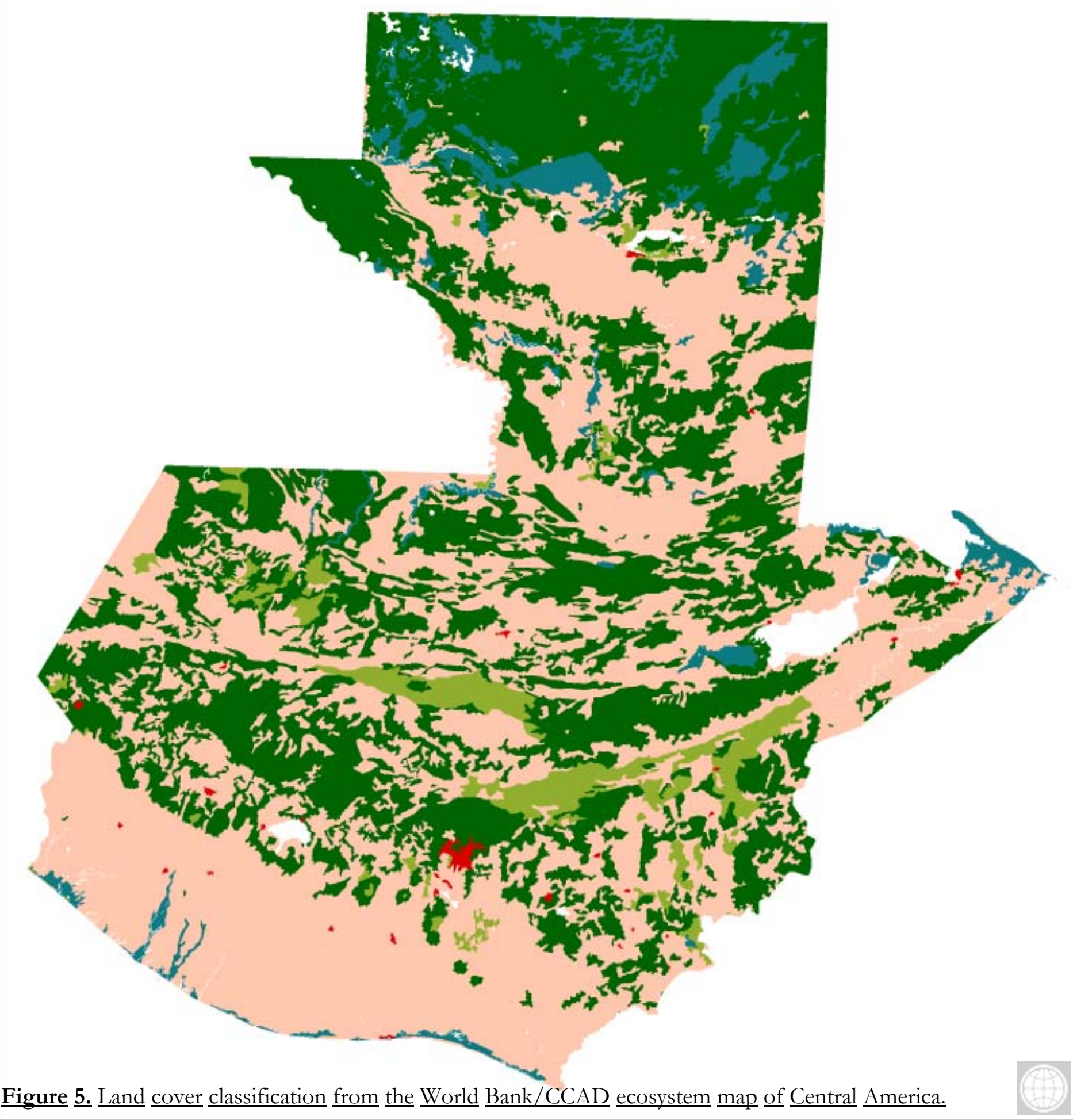




\section{Buffer zones}

A $1 \mathrm{~km}$ buffer zone either side of the interface between agriculture and forests on slopes greater than $8 \%$

Forest

Agriculture

Buffer

Instituto Geográfico Nacional "Ing. Alfredo Obiols Gómez"
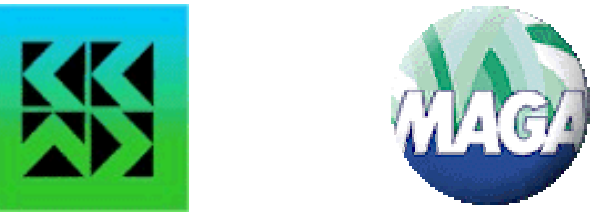

Lambert Equal Area Projection centered at $85 \mathrm{~W}$ and $13 \mathrm{~N}$

50
50

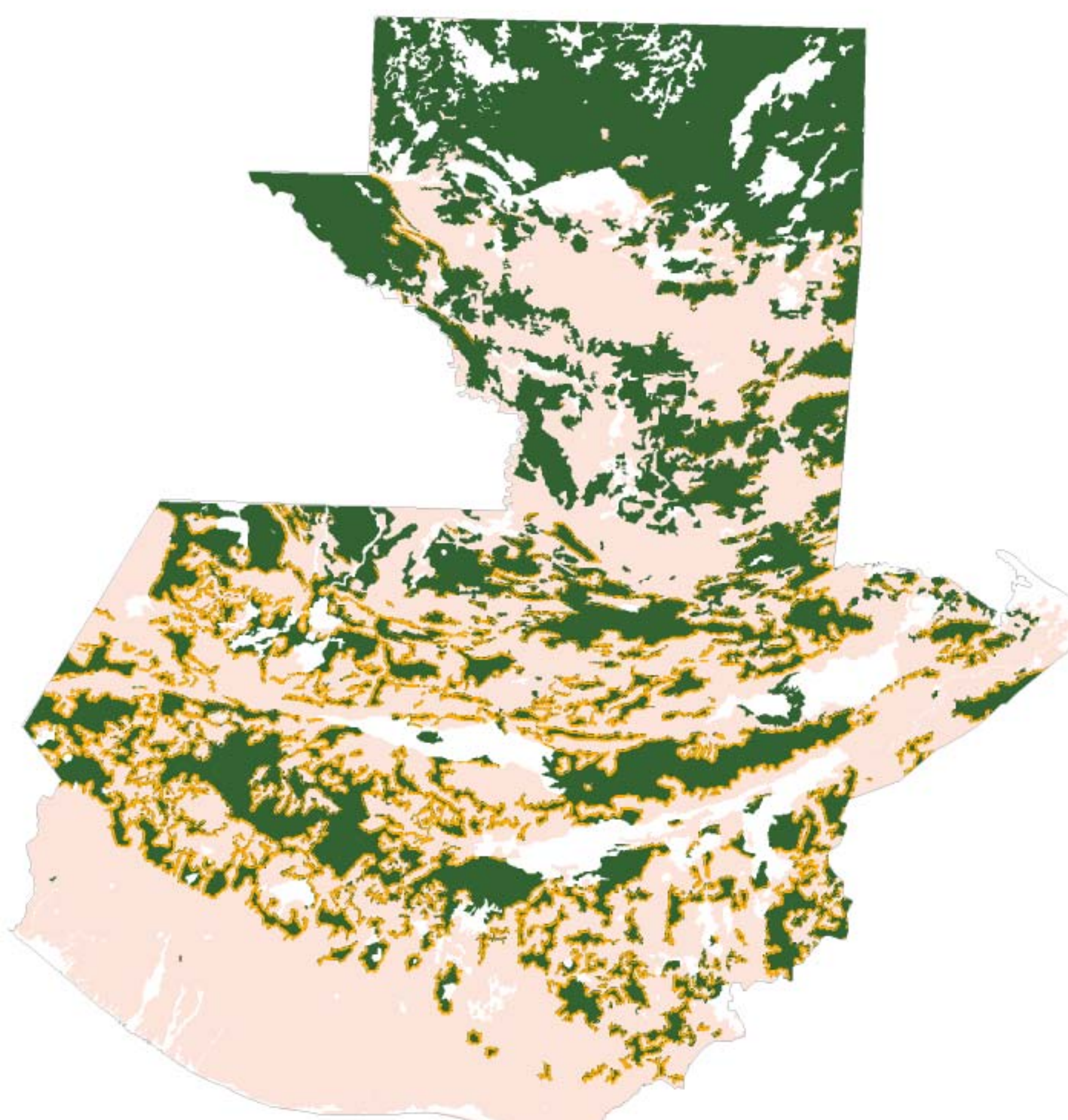

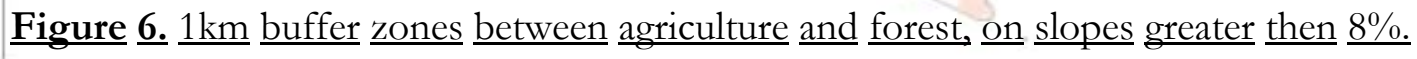




\section{Buffer as $\%$ of watershed}

Percentage area of each watershed in the $1 \mathrm{~km}$ buffer zone either side of the interface between agriculture and forests on slopes greater than $8 \%$

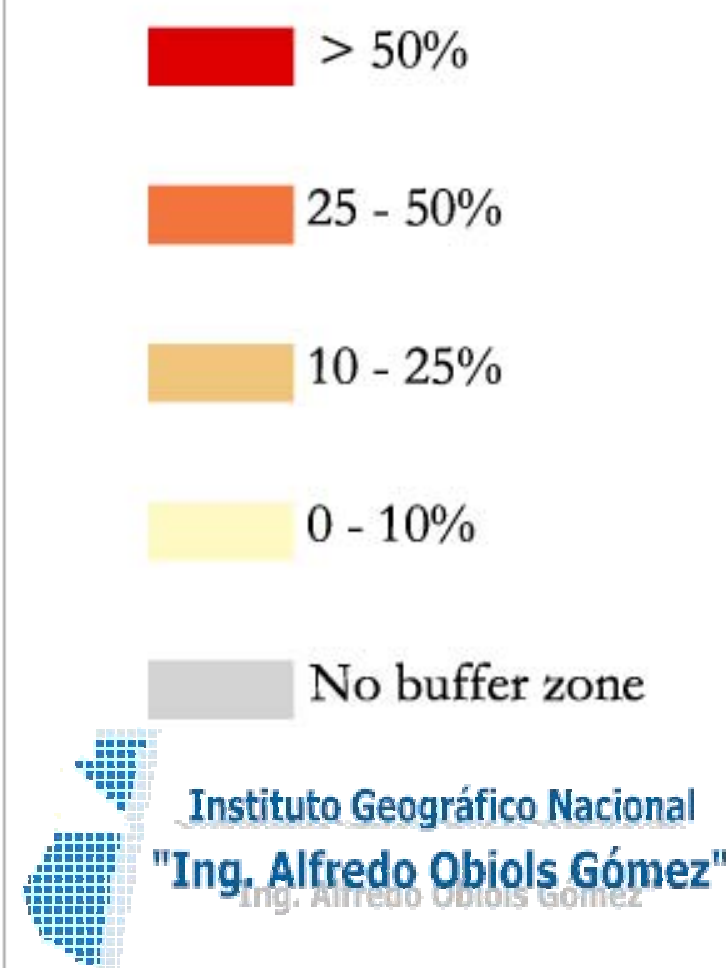
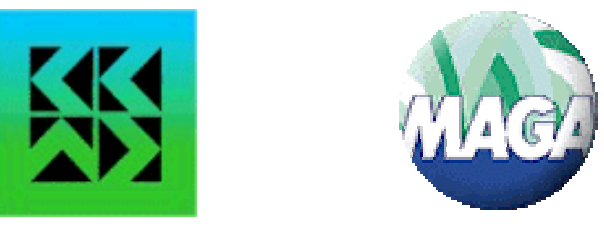

Lambert Equal Area Projection centered at $85 \mathrm{~W}$ and $13 \mathrm{~N}$

50

50

Kilometres

Figure 7. Percentage area of each watershed in the $\underline{1 \mathrm{~km}} \underline{\text { buffer }} \underline{\text { zone. }}$ 


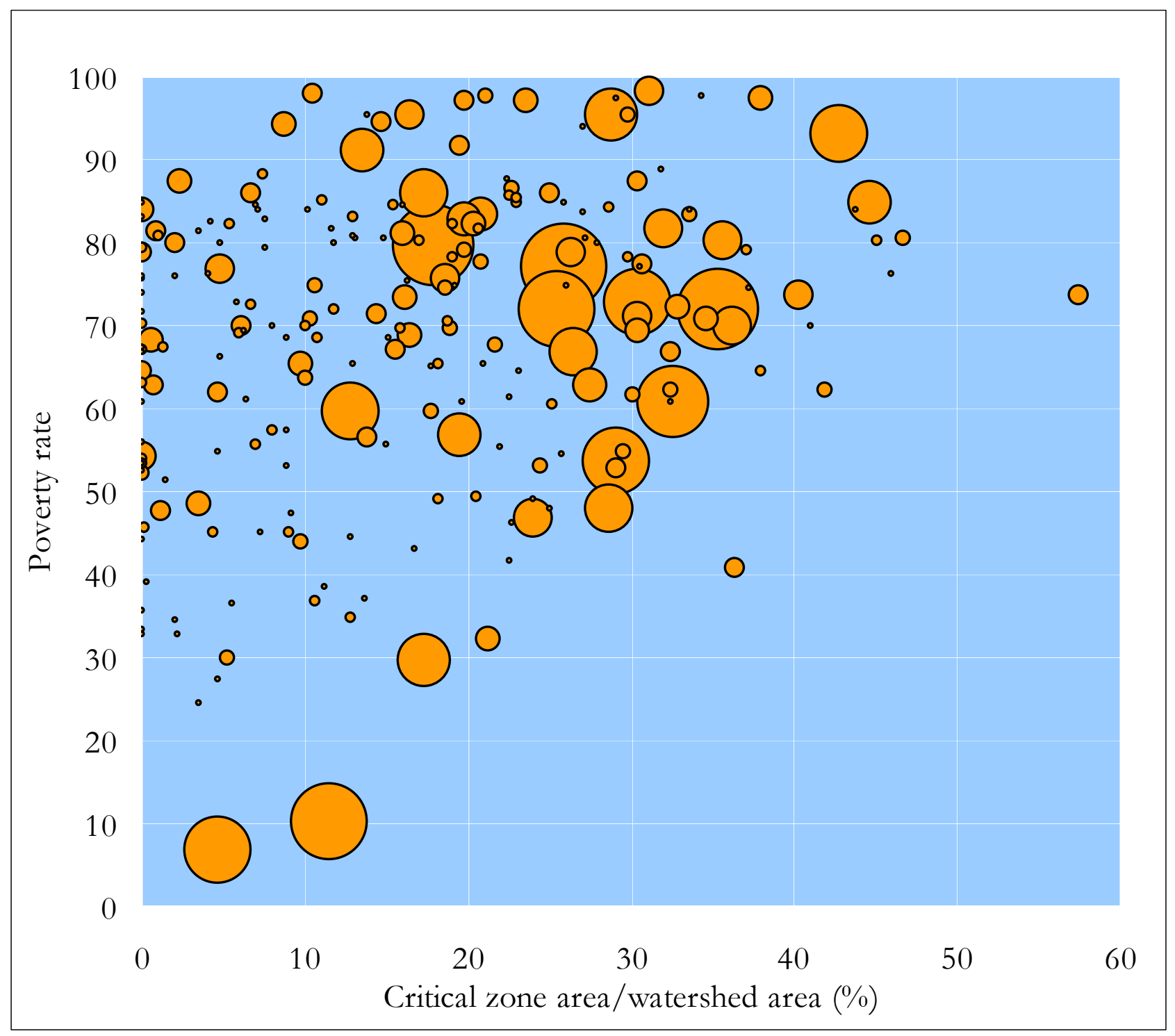

Figure 8. Guatemala: Poverty versus hydrological sensitivity by watershed (bubble size shows absolute number $\underline{\text { of }}$ poor people per 


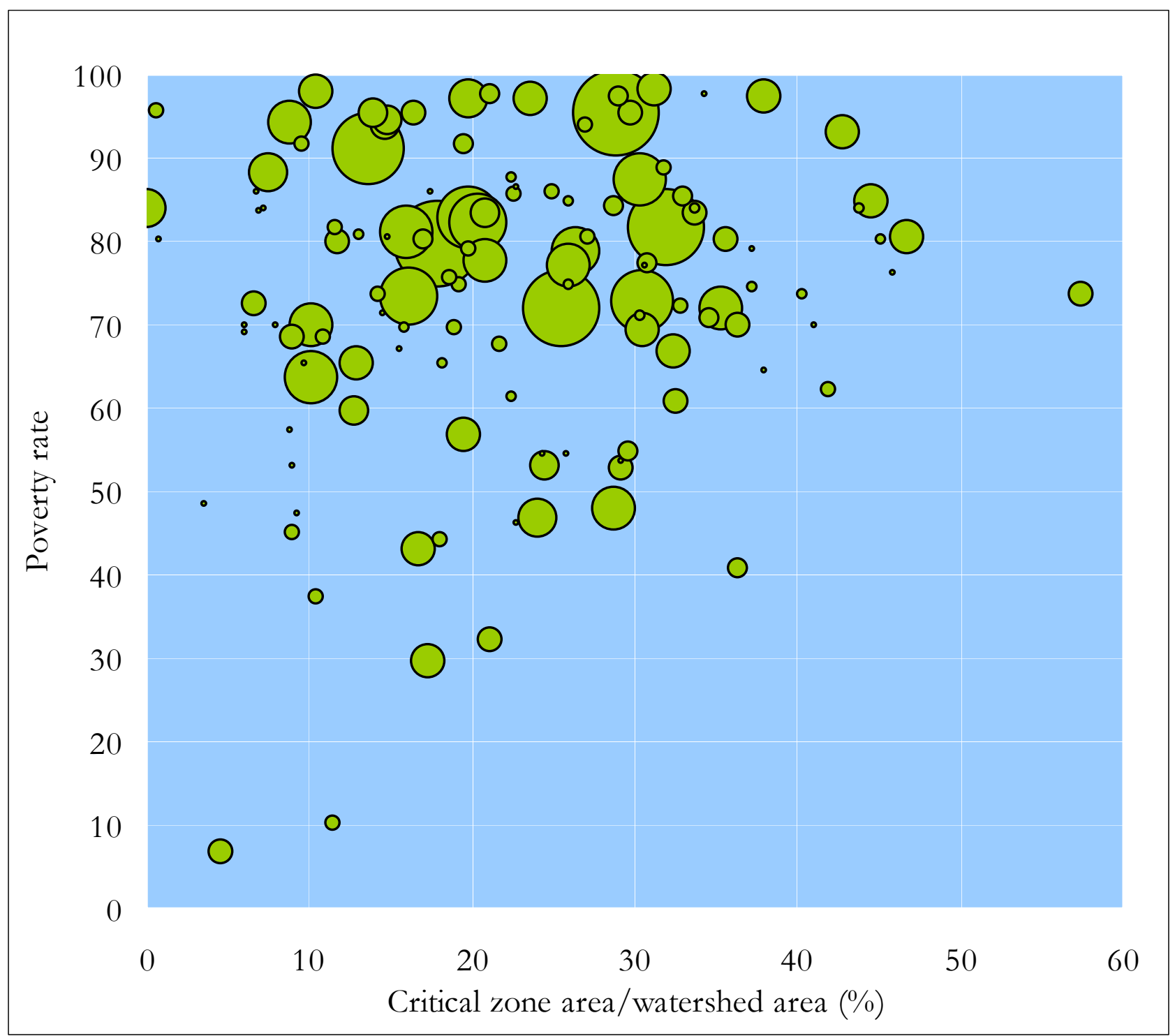

Figure 9 Guatemala: Poverty versus hydrological sensitivity by watershed (bubble size indicates absolute $\underline{\text { area }} \underline{\underline{\text { of }}} \underline{\underline{\text { montane }}} \underline{\underline{\text { forest) }}}$ 


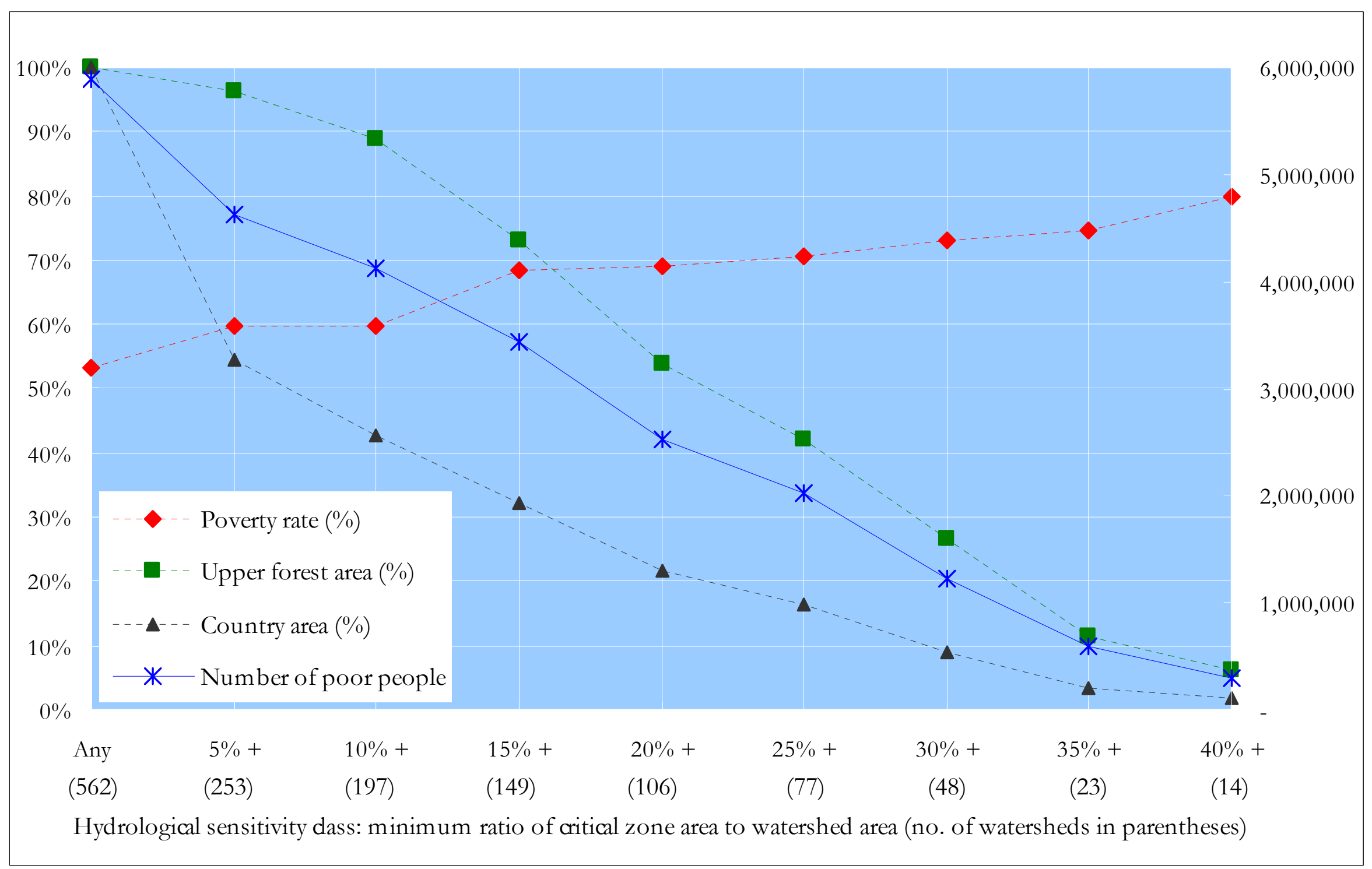

Figure 10. Guatemala: Characteristics of hydrologically sensitive watersheds 


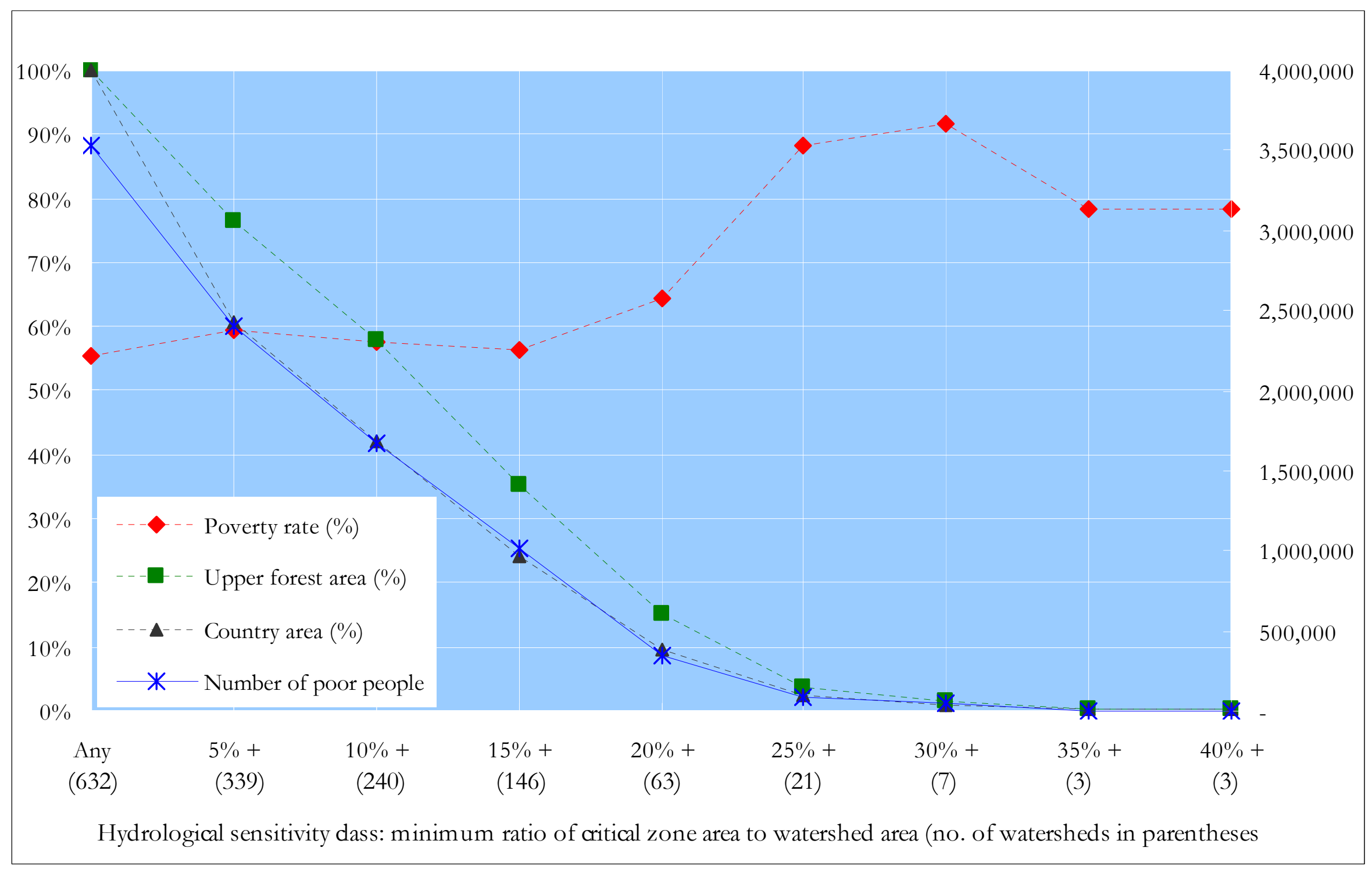

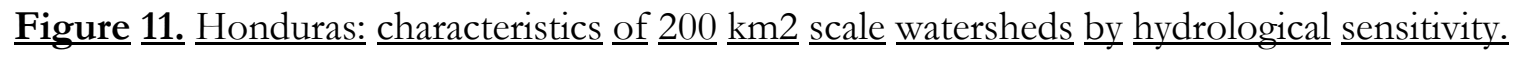




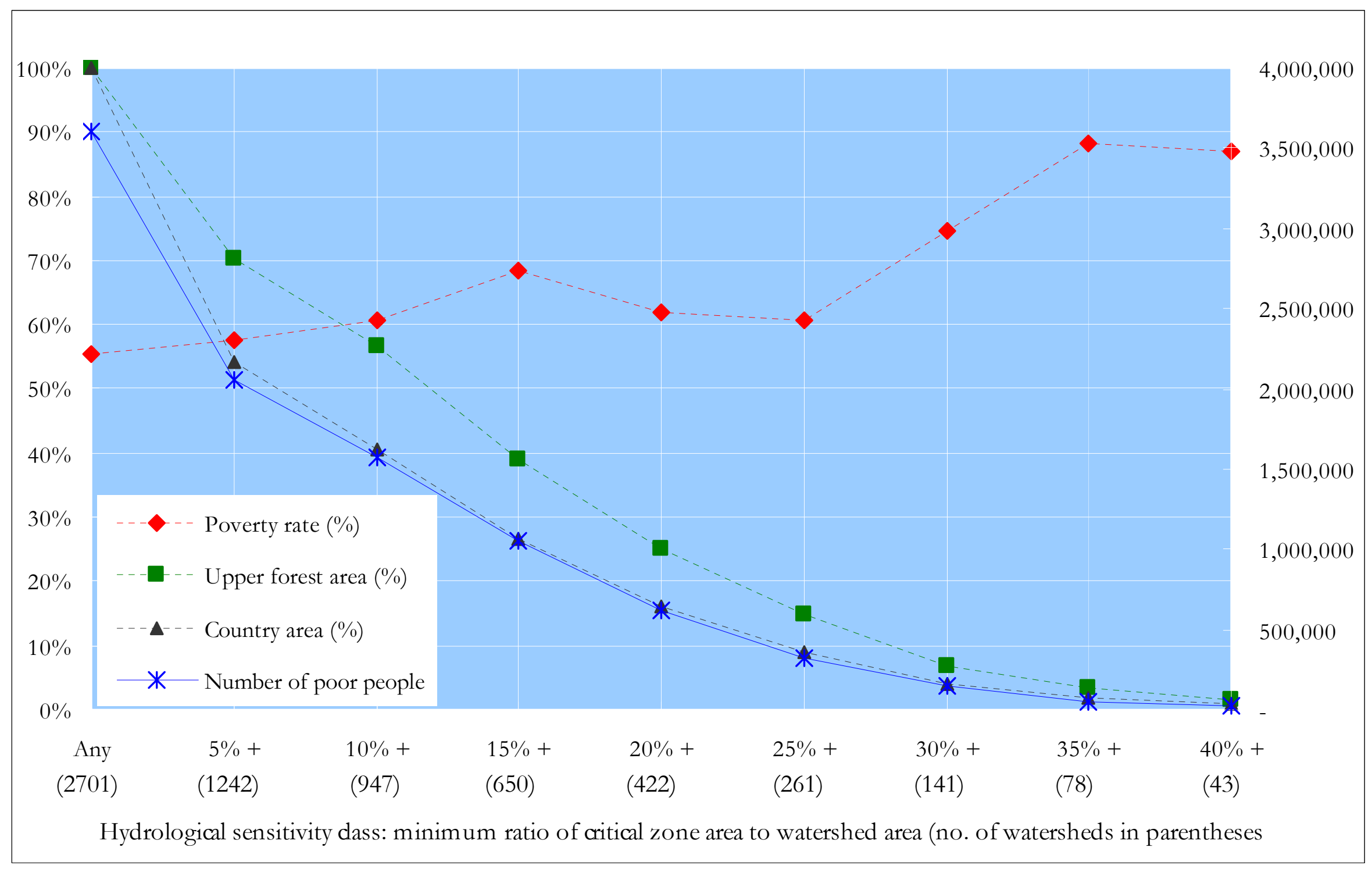

Figure 12. Honduras: characteristics of $\underline{50} \mathrm{~km} 2$ scale watersheds by hydrological sensitivity. 


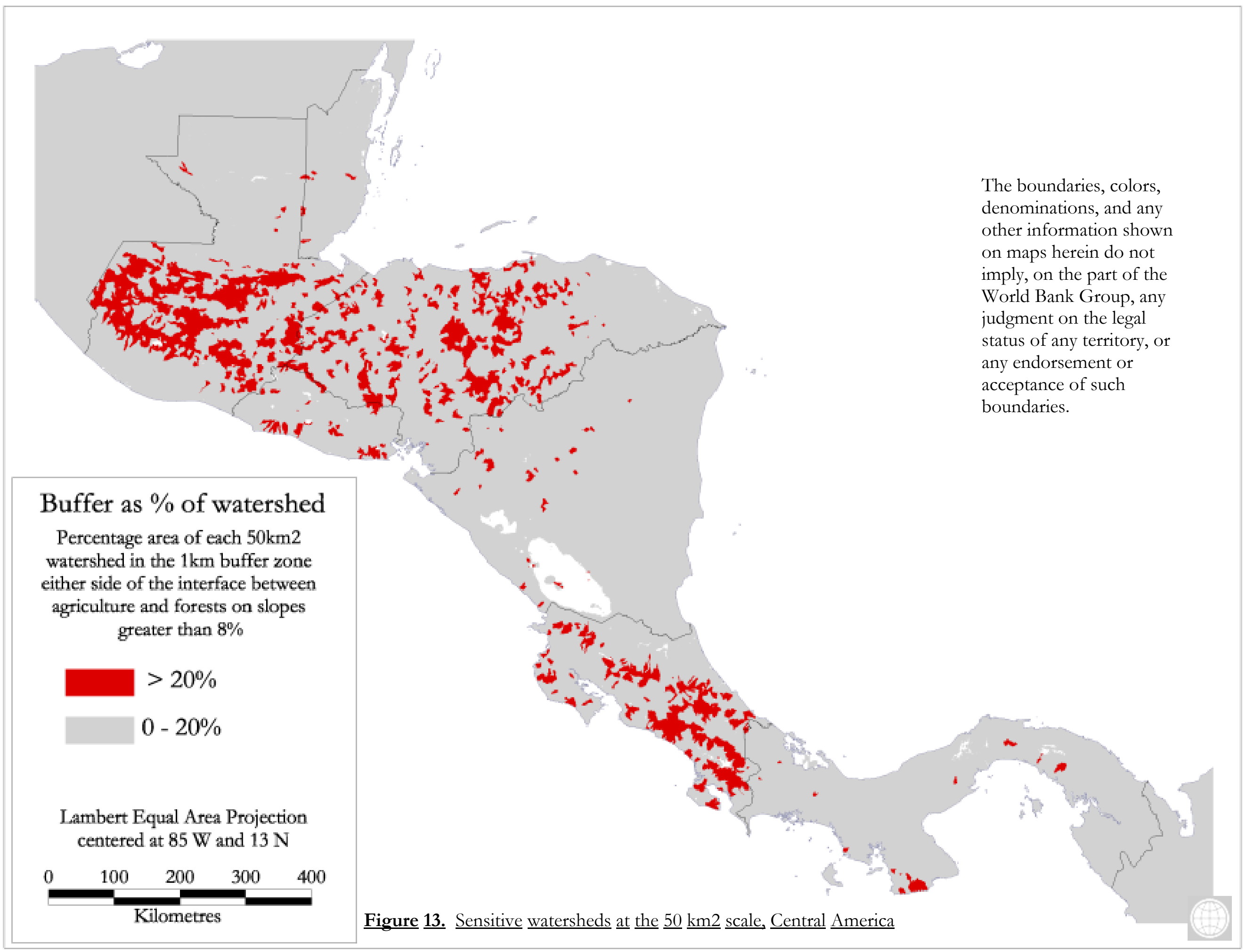

